\section{Application Of The Landscape Approach To The Study Of The Population Distribution Of The Fergana Valley}

\author{
Abduvaliev Hayitboy Abduganievich \\ Doctoral Student Of The Department Of Geography, \\ Fergana State University, Uzbekistan
}

\author{
G OPEN ACCESS \\ The American Journal of \\ Social Science And \\ Education Innovations \\ JULY 2020 \\ Page No.: 291-297 \\ Volume-II Issue-VII \\ PUBLISHED: 30 JULY 2020 \\ www.usajournalshub.com/inde \\ x.php/tajssei \\ Copyright: Original content \\ from this work may be used \\ under the terms of the \\ Creative Commons Attribution \\ 4.0 licence.
}

\begin{abstract}
The article describes the results of the study of some features of the population in the Fergana Valley, the region with the highest population and density in Uzbekistan and for the first time calculated and analyzed the population density of the Fergana Valley by landscape types.
\end{abstract}

Keywords: landscape, landscape approach, territorial organization, population density, population distribution, natural landscape factor, socio-economic factor.

\title{
Introduction
}

Well-known American geographer Richard Hartshorn once said in one of his works, "Landscape is undoubtedly the most important word in geographical language."[12]. Over the past century, the concept of landscape has been recognized by almost all major scientific schools available in world geography, despite various criticisms. The landscape approach has become widely used not only in natural geography, but also in historical, social, economic, political, cultural, military, geoecological, applied geographical research. In this regard, a well-known representative of the St. Petersburg School of Geography A.G Isachenko noted that in the 80 s of last century, it opened up unprecedented opportunities 
for geographical research based on the landscape approach [4].

In both economic and social geography, in the study of the territorial organization of society, it is common to work within the network of landscapes, which is the natural geographical basis of the regions $[2,4,6,7,10]$. The use of landscape approach, especially in population geography, has a high theoretical-methodological and practical potential. The landscape approach has not yet been widely used in scientific research on the geography of the population of the Fergana Valley, and the presented research can be considered as a scientific innovation in this regard to some extent.

\section{Goals and Objectives of the Work}

The purpose of the study is to identify and analyze the population density in the Fergana Valley in terms of landscape types. The following tasks have been identified within the framework of the set goal: 1) Separation of landscape types and calculation of area in the Fergana Valley; 2) calculation of the number of permanent residents living within the areas of isolated landscape species; 3) calculation of population density indicators for each landscape type and their mutual comparison.

\section{Main Part}

Taking into account various features of the landscape in conducting research on the territorial location of the population also increases the geographical importance of the study. In expressing landscape indicators in the territorial distribution of the population, it is necessary to distinguish the most important landscape criteria that affect the location of the population. Special attention is paid to geomorphological, climatic, soil and hydrological factors of the region as indicators characterizing the landscape criteria. It is also of practical importance in such studies to calculate population density based on landscape principles in the territorial distribution of the population. This, in turn, reveals real differences in the population density of the valley, but also determines the level of population of certain landscapes.

The use of landscape approach in determining the population density, employment of anthropogenic elements and anthropogenic changes in the region was analyzed by Sh. Sharipov, which proved the direct influence of anthropogenic elements in geosystems on population size and density. In calculating the population density in the landscape, the data of the population of the area corresponding to each landscape type are placed and the population density of the landscape is developed by dividing the population in each landscape by its area [11].

Studies on the territorial distribution of the population in the Fergana Valley emphasize the important role of hydrological factors and conditions in the territorial distribution of the population of the valley[4]. This aspect is directly related to the development of irrigated agriculture. Therefore, it is necessary to take into account that the most important link of 
the natural-landscape factor in the settlement of the population in the Fergana Valley is the dense hydrological network of rivers and streams located in the valley.

In calculating population density, the gross coefficient formed by dividing the population of a common administrative district by its area, which is common in economic geography, in many respects does not reveal clear differences in the area. Although a district has a population density of more than 340 people (Fergana district), it has a high population density in areas that are suitable for its population (areas close to rivers or streams, conical distributions), and very low population density in low mountainous areas. This limits the ability to know the full state of the area.

In order to shed more light on the above, an assessment was made, taking into account the urgency of determining the population density in the modern landscapes of the Fergana Valley. According to him, as a primary indicator, the number of the most recent population by neighborhood, village and urban gatherings was studied using GIS programs of the Fergana Valley landscape map at a scale of 1: 200,000. A map of the landscapes of the Fergana Valley has been proposed by various landscape scientists [1. 3]. However, the landscape map proposed by A.D Nikanorova at Moscow State University, which combines the latest achievements in landscape science and cartography, is quite well developed. A.D Nikanorova identified 7 natural landscape types in the Fergana Valley based on the morphological features of mountains and lowlands. It also divided 11 landscape classes into territorial differences in land cover. Given that it is not possible to distinguish such a large difference in population within the smallest natural territorial units, only 7 natural landscape types were selected for our study [8]. The boundaries of the selected landscape types have been defined and the corresponding Neighborhood Citizens' Meeting (NCM), Rural Citizens' Meetings (RCM) and Urban Citizens' Assemblies (UCA) population was studied. In this case, when the area of an NCM, RCM, and UCA corresponds to two landscape types, the results were generalized for that area to which $2 / 3$ of the area belongs. As a result, the population density of modern landscapes of the Fergana Valley was developed.

According to the survey, the population density of Pop district of Namangan region in terms of gross population density was 75.3 people, it can be seen that the level of tension in the district is not high, the capacity to organize the population in the district is maintained at a high level. However, according to the results of our research, the territory of Pop district is divided into landscape zones of low mountains, foothill proluvial plains, hills and alluvial plains. When the current population density was determined separately, it was found that the low mountainous area of the district occupies about $53 \%$ of the district area, where 48,451 people ( $22.2 \%$ of the total population of the district) live. The population density for this landscape region is 31.4 people per $1 \mathrm{~km}^{2}$. The foothill proluvial plains of the district occupy $19 \%$ of the area of the administrative district, where $34.5 \%$ of the population lives. The density in this region is 136.7 people per $1 \mathrm{~km}^{2}$. The landscape area of the hills is $17 \%$ of the area, with a population of 39,471 (18\% of the total population of the district) and a 
density of 79.8 people. The alluvial plains landscape zone occupies $11 \%$ of the district's territory and is home to 55,502 people (25.3\% of the district's total population). The population density in this area is 173.4 people per $1 \mathrm{~km}^{2}$.

This is also the case in Sokh district, the most sparsely populated area in the Fergana region. The total population density in the district is 250.6 people per $1 \mathrm{~km}^{2}$, as of January 1,2019 . This shows that the population density in the district is 2.2 times less than the total of Fergana region (555 people), and 2 times less than the total of the Fergana Valley (518.9). However, when the situation is divided by natural landscape types, the area of the district corresponds to the area of low mountains and alluvial-proluvial plains of the hill range. When the population density for these two landscape types was calculated by the above method, the population density in the lowlands of the district was 134.1 people, and in the alluvial-proluvial plains of the hill range was 716.5 people. It can be seen that although the district is recognized as a sparsely populated area at a glance, its original condition is much higher than the overall performance of the province and the valley.

According to the study, administrative districts corresponding to each landscape type were identified. The area of each landscape type and its share in the valley landscapes were calculated. The existing population and its density were also identified in the landscape type.

According to this methodology, a number of advantages can be seen when analyzing the current population and population density of the Fergana Valley by zoning the valley into 7 landscape types, separated in terms of natural landscape. First, the exact population densities of the regions are separated. Second, the population and its density are known in the separate landscapes of each administrative district. Third, the individual landscapes of all administrative districts are generalized, making it possible to form the total population of the valley landscapes and its density.

When analyzing the population of the landscapes of the Fergana Valley, the low mountain landscape accounts for only $1.3 \%$ of the population. However, the area it occupies is larger than the landscape area of the foothill proluvial plains, hills, alluvial-proluvial plains of the hill range, and alluvial plains. Due to the size of the area but the small population, the density of the valley population in this landscape is 51.8 people per $1 \mathrm{~km}^{2}$. This means that the population density of the region is 10 times smaller than the general level of the valley, and almost 18 times smaller than the area of the proluvial-alluvial plains of the cone distribution. The highest landscape type of the valley in terms of population density are the proluvial-alluvial plains of cone distributions. Its population density is 868.8 people per 1 $\mathrm{km}^{2}$.

The proluvial-alluvial plains of the cone distribution are inhabited by $45.9 \%$ of the valley population in the landscape zone. The second most dense region is the alluvial plains of the Syrdarya, Naryn and Karadayo plains, with a density of 843.7 people per $1 \mathrm{~km}^{2}$. But this landscape region occupies only 9 percent of the territory. In terms of population density, the third landscape region is the landscape of the alluvial-proluvial plains of the Adir range, 
where the density is 817.5 people per $1 \mathrm{~km} 2$. These results show that the proluvial-alluvial planes of the cone distribution, the alluvial plains and the alluvial-proluvial plains of the hill range have some advantages in terms of population living and economic use. Therefore, the population density in these landscape regions differs sharply compared to other landscape regions. In terms of density, these 3 landscape regions are home to a total of 7012897 people, or as of October 1, 2019, about 3/4 of the valley's population (72.5 percent). However, these areas do not occupy even half of the valley in terms of area (Table 1 ).

Table 1

Population density in the landscape regions of the Fergana Valley

\begin{tabular}{|l|l|l|l|l|}
\hline & $\begin{array}{l}\text { Area } \\
\text { landscape } \\
\text { types } \\
\text { (thousand } \\
\mathrm{km}^{2} \text { ) }\end{array}$ & $\begin{array}{l}\text { Number of } \\
\text { permanent } \\
\text { residents } \\
\text { living } \\
\text { landscape } \\
\text { types (person, } \\
1.01 .2019)\end{array}$ & $\begin{array}{l}\text { Population } \\
\text { density } \\
\text { (Per 1 km } \\
\text { area, } \\
\text { person, } \\
01.01 .2019 \\
\text { ) }\end{array}$ & $\begin{array}{l}\text { Percentage } \\
\text { of valley } \\
\text { population in } \\
\text { landscape } \\
\text { type (as a } \\
\text { percentage) }\end{array}$ \\
\hline Low mountains & 2,399 & 124142 & 51,8 & 1,28 \\
\hline $\begin{array}{l}\text { The alluvial- } \\
\text { proluvial planes } \\
\text { of the Hill range }\end{array}$ & 1,688 & 426251 & 252,5 & 4,41 \\
\hline Hills & 2,288 & 498562 & 217,9 & 5,15 \\
\hline $\begin{array}{l}\text { Proluvial-alluvial } \\
\text { planes of conical } \\
\text { distributions }\end{array}$ & 1,402 & 1146031 & 817,5 & 11,85 \\
\hline $\begin{array}{l}\text { Pre- } \\
\text { mountainous } \\
\text { proluvial plains }\end{array}$ & 5,116 & 4444952 & 868,8 & 45,95 \\
\hline $\begin{array}{l}\text { Ancient alluvial } \\
\text { plains }\end{array}$ & 4,066 & 1611248 & 396,3 & 16,66 \\
\hline Alluvial planes & 1,685 & 1421914 & 843,7 & 14,70 \\
\hline Total & $\mathbf{1 8 , 6 4 5}$ & $\mathbf{9 6 7 3 1 0 0}$ & $\mathbf{5 1 8 , 8}$ & $\mathbf{1 0 0 , 0 0}$ \\
\hline
\end{tabular}

The table is based on the data of the authors on A. Nikanorova [8] and the State Statistics Committee of the Republic of Uzbekistan [10]

It should also be taken into account that the population density in the landscapes is influenced by the process of industrialization and socio-economic factors of the region, in contrast to the fact that this landscape is very favorable. It is noteworthy that the dense population of Namangan, Fergana and Andijan is due to its location in favorable landscapes, as well as the development of sectors of the economy in recent years, in particular, the active process of industrialization. Taking into account the possibilities of the landscape type 
in the calculation of population density, and the use of economic indicators in the assessment of landscape possibilities strengthens the connection of science with practice.

\section{Conclusion}

The analysis of the role of landscapes in population distribution in general has been conducted by many researchers. Most researchers have compared the population density to the areas in which they are concentrated, noting that the maximum population density falls on a wetland or river terrace, and decreases as it moves away from the riverbank to the highlands. It is also important to compare population density with the ecological potential of landscapes. The population is mainly concentrated in areas with high ecological potential. Many ancient cities appeared in such places (Margilan in the Shohimardonsoy stream, Kokand in the Sokh river) [7]. From the above, it is expedient to take into account the diversity of their landscape potential in the socio-economic assessment of regions. It is also important that human life is directly related to nature, that there should be normative indicators for each region that have as little impact on its nature as possible, that do not disturb the balance, and that normative indicators of landscapes or lands should be defined [9]. Also, the study of the average population in rural areas, the distribution of the rural population in rural administrative districts on the basis of the density of rural areas should also serve as a necessary socio-economic condition [10]. Taking into account the natural and landscape features of the region in the rational placement of the population and the economy allows you to make the most of the invaluable opportunities of nature. At the same time, it creates a preliminary database for the normalization and optimization of the level of anthropogenic pressure on landscapes in areas with high population density today.

\section{References}

1. Alibekov L.A. New approaches to the conjoint study of mountainous and lowland landscapes (on the example of Central Asia) // Geography and natural resources. Novosibirsk: 1992. No. 3, - p.29-37.

2. Ahmadaliev Yu.I. Geoecology of land use. Tashkent: Science and Technology, 2014. -p. 340.

3. Boymirzaev K. Use and protection of oasis landscapes of Fergana valley. Tashkent: Fan, 2007.-p. 130.

4. Jumaxanov Sh. Improving the territorial composition of the population of Namangan region. Geog. fan. nom. ... diss. avtoref. Tashkent: 1998. -p. 22

5. Isachenko A.G. Methods of applied landscape research. London: Nauka, 1980. -p. 222.

6. Kashin A.A. Investigation of the landscape organization of the territory of Udmurtia as a factor of economic development and settlement of the population. Diss. Cand. geog. sciences. Izhevsk: 2015. -p. 184. 
7. Komilova N.O'. Geographical aspects of ethnoecological culture (on the example of Fergana valley). Geogr. fan. Doctor of Philosophy (PhD). diss. avtoref. Tashkent: 2019. -p. 48.

8. Nikanorova A.D. Landscape-geoecological substantiation of water use optimization in irrigated agriculture in the Fergana Valley. Diss. Cand. geog. sciences. Moscow: 2015. -p. 169.

9. Rahmatullaev A. Geographical optimization of the ecological situation in the geosystems of the Middle and Lower Zarafshan oasis. Geogr. fan. doc. (DSc) .diss. avtoref. Tashkent: 2018. -p. 59.

10. Fedorko V.N; Kurbanov Sh.B. Typology of the lower administrative regions of Uzbekistan by the forms of rural settlement // Information of the Geographical Society of Uzbekistan. 2016. Volume 45. - p. 72-80.

11. Sharipov Sh.M. The use of landscape-typological maps in the calculation of population density // Information of the Geographical Society of Uzbekistan. 2009. Volume 34. - p. 166-168.

12. Harthshorne R. The nature of geographie. A critical survey of current thogth in the ligth of the past. Pensilvania: Association of American Geographers, 1939. -p. 469.

13. https://stat.uz/uz/ Data of the State Statistics Committee of the Republic of Uzbekistan. 